\title{
The MusLiM WorLd
}

\begin{tabular}{lll}
\hline \hline Vol. LXXXI & July-October 1991 & No. 3-4, 1991 \\
\hline
\end{tabular}

\section{HUMOR IN THE QUR'ĀN}

He said, "In a certain city there was a judge who neither feared God nor regarded man; and there was a widow in that city who kept coming to him and saying. 'Vindicate me against my adversary.' For a while he refused; but afterward he sald to himself, "Though I neither fear God nor regard man, yet because this widow bothers me, I will vindicate her, or she will wear me out by her continual coming." "(Luke 18:2-5).

While there is no doubt that scripture ${ }^{l}$ is serious matter and ought to be taken as such, there is reason to believe that humor is not entirely alien to the spirit of scripture. ${ }^{2}$ The God of revealed books does not laugh like the residents of Mount Olympus, and so one should not expect to find in His books uproarious laughter: chuckles and smiles are all one can hope for. It is also true that the moments which occasion these chuckles and smiles are rare. But they are, precisely for that reason, precious. The paper will attempt to highlight some of those moments with reference to the Islamic scripture, the Qur’ān.

Why should one look for humor in scripture at all? First, scripture deals with and reflects a human situation, and, barring the gallows and the gas chamber, every human situation, especially if it involves extensive human interaction over a long period of time, is likely to contain an element of humor at some point. ${ }^{3}$ The possibility of finding humor in scripture is therefore not completely excluded. The possibility is, in fact, increased if we keep in mind that the Qurªn was originally delivered in an oral situation, which, by

\footnotetext{
'By scripture is here meant the revealed books of the Judeo-Christian-Islamic tradition.

${ }^{2}$ Reinhold Niebuhr, who otherwise holds that humor cannot resolve "the ultimate incongruities of life" in "Humor and Fatth" M. Conrad Hyers, ed., Holy Laughter: Essays on Religion in the Comic Perspective (New York: Seabury Press, 1969), p. 146, grants that "the absence of laughter in the most ultimate experience of life does not preclude the presence of laughter as a suffused element in all experience" (pp. 142-43). He accordingly makes room for humor "in the vestibule of the temple" if not "in the holy of holies" (p. 149). He also remarks, "The saintliest men frequently have a humorous glint in their eyes" (p.142).

In fact, even the most tragic circumstances have not failed to produce some humor: there is, as we know, "gallows humor." A number of scholars have written about Jewish humor during the Holocaust and other periods of suffering. See Israel Knox. "The Traditional Roots of Jewish Humor," in Hyers, Holy Laughter; and Hyers. "The Dialectic of the Sacred and the Comic," ibid. pp. 232-33; Robert Alter. "Jewish Humor and the Domestication of Myth." in Sarah Blacher Cohen, ed. Jewssh Wry (Bloomington and Indianapolis: Indiana University Press. 1987).
} 
definition, is dynamic. As Elton Trueblood says, "We must remember that words are made very different in connotation by the tone of the voice and by the look in the eye of the speaker. There are things which we can say with a smile, but which cannot be said, without of fense, with a straight face."4 As such, an alertness to the possibilities of the Qur'anic text, including the possibility of humor, cannot hurt; failure to remain alert might. Not to trivialize a Biblical parable, it is best to be ready like the five wise maidens. Second, it will be agreed that scripture contains satire: the disbelievers are to be condemned, the wrongdoers to be criticized, and so on, and satire comes in handy for that purpose. But why not humor, one might ask? Is satire becoming of scripture but humor is not? Does satire serve a noble purpose but humor is an exercise in flippancy? That may not be the case, for humor and levity are not necessarily the same. ${ }^{5}$ Third and most important, humor is one of the devices we use to make a point. Prophets and scriptures, too, have a point to make, and it is not to be supposed that they would disavow the use of this device as a matter of principle. As we shall see later, humor can be used to convey a religious insight or elucidate a theological teaching.

There are two reasons why one feels uneasy at the mention of humor in scripture. The first has to do with the prevalent view that scripture should appropriately give rise to feelings of reverence and awe. The proper attitude to adopt toward scripture, we tend to think, is one of solemn respect, and anything that takes away from the solemnity of scripture is considered suspect. ${ }^{6}$ As such, to attempt to see humor in scripture would be like betting on a horse that is not even in the race. Second. as was noted above, instances of humor in scripture are admittedly small in number. In other words, the stuff scriptures are normally made of-theology-surrounds those instances, or shall we say crowds them, thus obscuring them from view. Precisely for this reason it is necessary to isolate the element of humor in scripture from its theological context-the task is akin to reaching the eye of the hurricane-and to dwell on that element for some time in order to reveal its potential.

Studies of humor in the Bible exist. ${ }^{7}$ The notes that make up the present study are, to my knowledge, the first attempt to look for humor in the Qur`an.

'Elton Trueblood, The Humor of Christ (New York: Harper \& Row, 1964), p. 123.

${ }^{5}$ See Hyers, "The Comic Profanation of the Sacred," in Hyers, ed. Holy Laughter, "There is a qualitative difference between taking something humorously and taking it lightly" (p. 13).

${ }^{6}$ See Trueblood, The Humor of Christ, "Religion, we think, is serious business, and serious business is incompatible with banter." p.15.

'See Gary Webster, Laughter in the Bible (St. Louis. Missouri: The Bethany Press, 1960), Jakob Jonsson, Humor and Irony in the New Testament (Reykjavik, Iceland: Bokautgafa Menningarsjods. 1965), Elton Trueblood Hyers, ed.. Holy Laughter; idem. The Comic Vision and the Christian Farth: A Celebration of Life and Laughter (New York: The Pilgrim Press, 1981); Paul H. Grawe. Comedy in Space, Time, and the Imagination (Chicago: Nelson-Hall, 1983), chs. 17 ("Old Testament Comedy") and 18 ("Gospel Comedy"). 
Franz Rosenthal in his Humor in Early Islam ${ }^{8}$ speaks of humor in the Prophetic Tradition but not in the Qurª̆n. He writes:

The otherwordliness of Islam did little to stop the actual enjoyment and literary appreciation of humor. With all his seriousness and the foreboding doom, the Prophet Muhammad himself possessed much cheerful humanity, and his followers through the centuries have always preserved a good-natured love of jokes and pranks. ${ }^{9}$

Rosenthal, as can be seen, passes from pre-Islamic folk or Bedouin humor to the "much cheerful humanity" of the Prophet-a reference to the instances of humor in Hadīth-without saying anything about the Qur'ān. Alfred North Whitehead spoke of the "total absence of humor from the Bible."10 Happily he was proved wrong in his view about the Bible by later writers. ${ }^{11}$ Rosenthal does not explicitly make such a statement about the Qur'an, but as the above quote suggests, as indeed will a reading of the whole book, he considers the Qur'an to be devoid of humor. Charles Pellat, too, in his article "Seriousness and Humour in Early Islam,"12 finds no instances of humor in the Qur'ān. The present study is of fered as a supplement to the works of Rosenthal and Pellat.

We now turn to the Qur'ann. We shall begin by citing two examples to show that the Qur'an does not regard humor as a contraband item. In S. 11:69-73, angels visit Abraham and give him the good news of the birth of a son. Abraham's wife, who is at some distance but is listening intently, breaks into laughter. Her laughter was caused by incredulity, as the text indicates: "Woe to me,' she said, 'shall I give birth, being an old woman?' "13 The piece of news must have struck her as somewhat funny: a woman giving birth at such an advanced age! $!^{14}$ And she adds, pointing to Abraham: "And here is this husband of mine! An old man! This is a strange thing indeed." The demonstrative hadha in hadha ba'li shaykhan was probably accompanied by an appropriate manual gesture, suggesting a combination of surprise, hope, and disbelief, and adding to the gentle humor in her remark. In S. 27:17-18, Solomon, who understands animal language, hears an ant instructing its companions at the approach of Solomon's army: "Ants, enter into your holes, lest Solomon and his troops should crush you, without being aware of it." Solomon, according to

\footnotetext{
${ }^{8}$ Leiden: E.J. Brill, 1956.

${ }^{9}$ Ibid, p.3.

${ }^{10}$ Quoted by Sarah Blacher Cohen, "Introduction: The Varieties of Jewish Humor," in Cohen, p.1.

${ }^{11}$ See ibid., pp. 1-2.

${ }^{12}$ In Etudes sur Ihistorre soctoculturelle de J'Islam 7e-15e s. (London: Variorum Reprints, 1976), pp. 353-62.

${ }^{13}$ I have given my own translation of the Qur'anic verses cited in this paper.

${ }^{14}$ See Genesis 18:12-15. References to the Bible are to the Revised Standard Version, unless otherwise indicated.
} 
the passage. "smiled, breaking into laughter." He, too, must have seen the situation in a humorous light. These two examples may be said to provide a "sanction" for humor in scripture, if such a sanction were needed..$^{15}$

What definition of humor shall we use when we go looking for humor in scripture? To define humor is, of course, not easy. ${ }^{16}$ Jakob Jónsson's def inition is simple and practical-"comical sayings and events. expressions and situations, that might provoke smile or laughter." ${ }^{17}$ As for "What is the essence of the comical?"-Jónsson suggests that the comical implies playfulness and amusement. ${ }^{18}$ While Jónsson's definition does not point to what many would call the "most essential ingredient" of humor-geniality or kindliness--the words "playfulness" and "amusement" already hint at it; in comparing humor with wit, moreover, Jonsson clearly states the importance of this ingredient. We shall, therefore, take his def inition along with the elaboration he offers of it. ${ }^{19}$ In the next section we shall attempt to identify a few instances of humor in the Qur'ann, examining, in the section to follow, the technique and function of humor in the Qur’àn.

\section{INSTANCES OF HUMOR IN THE QUR'ĀN}

\section{The Uses of a Wooden Staff}

In the first part of S. 20 Moses is presented as returning from Midian in the company of his family. At one place he catches sight of a fire and asks his family to wait for him while he goes to fetch the fire (verse 10). Upon

${ }^{15}$ S. 86:14, which says that the Qur'an is no "joking matter" (hazl) is of course in a totally different vein. Nor can a verse like 9.82 be adduced to prove the absence of humor in the Qur’ān.

${ }^{16}$ Jean Paul Richter spent years analyzing collected definitions of the comic. In the end, he solemnly declared that their one common quality is that they themselves are comical." Webster, Laughter, p.29. See also Wylie Sypher (quoted in Trueblood, The Humor of Christ, (p. 35). "We do not really know what laughter is or what makes us laugh."

${ }^{17}$ Jónsson. Humor. p. 17. In using "humor" in this sense, I shall not be concerned with the question whether the ultımate triumph of Good over Evil constitutes humor or not. In fact, the use of the word "humor" for such a triumph seems to be a misnomer. Niebuhr (in Hyers, ed., Holy Laughter, p. 139) says that "there is no humour in the scene of Christ on the Cross." Chad Walsh (ibid.. p. 245) takes issue with that. saying that "The comedy lies in the solemnity of the crucif 1ers who so humorlessly sought to do one thing while actually dong the quite different thing intended by God." Using Jónsson's definition, one would support Niebuhr rather than Walsh, who, one suspects, has philosophized humor out of existence by means of his construc tion of the incident of Christ on the Cross--much as Cleanth Brooks generalized irony nearly out of existence by means of his definition of it: an ironical statement is one that "acknowledges the pressures of the context" (see his "Irony as a Principle of Structure." in Morton Dauwen Zabel, ed., Literary Opinion in America, 2 vols., 3rd editıon, revised (New York: Harper Torchbooks. 1962). 11. 732.

${ }^{18}$ Jónsson. Humor. p. 17.

${ }^{19} \mathrm{Sec}$ ibid.. pp. 19-20. It will be noticed that Jonsson relates the humorous to the comical (see 1 bid., pp. 169 ff.), withoul. however, equating the two. His definition raises questions about the relationship between humor, comedy, and laughter. We shall content ourselves with the remark that humor is not always kindly: there is, for example. sardonic hurnor which might be lacking in geniality altogether. Within the limits of the present study, however. Jónsson's definition would be adequate in most if not all cases. 
approaching the fire, he hears a voice telling him to take off his shoes because he is in a sacred valley and that it is God who is speaking to him. He is further told that he has been chosen by God to receive revelation and is instructed to establish prayer. Up to this point, the conversation has been one-sided, God being the speaker. But there is a sudden shift in the level of the talk. God asks Moses, "And what is that in your hand. ${ }^{20}$ Moses?" Moses, who has been listening in rapt attention, is unprepared for the question. Having no idea that he is about to receive the miracle of the staff, he begins to expatiate on the uses of the staff (verse 18). He first identifies the thing: it is a staff. But he does not stop there-he seems to be in love with his staff-and goes on to list the ways in which he can use it-to lean on when he is tired and to shake down leaves from trees for his flock. ${ }^{21}$ Having said this, he probably senses that he is providing these details to the wrong party. But the staff is important to a shepherd, and its many other uses deserve at least a passing reference. And so Moses makes an appropriate summary statement: "And I have other uses for it, too." He is not unlike a child who, having been asked by an engineer to identify the toy in his hand, launches into a serious disquisition on the various possible uses of the toy.

\section{The Young Man and the Diving Fish}

S. 18:60-64 relates the story ${ }^{22}$ of Moses and the young man who accompanied him on a certain mission. Moses, in compliance with a divine command, undertakes a journey in the river in order to meet a certain person-tradition calls him Khidr--who, as an agent of God, has been endowed by God with certain special powers. At a certain point during the journey Moses and the young man stop to take a rest on the shore by a rock. Moses asks his companion to take out the food they have brought with them, which consists of $f$ ish. The companion finds himself in a difficult situation, for who would believe this?-at certain point during their journey, the fish leapt out of the boat and disappeared into the river. The young man himself is a witness to the event, but Moses is not likely to believe him and may even reprimand him for telling a lie or being negligent. In any case, he is reluctant to break the news to Moses. But he must explain what happened. Anxious to put himself in the clear, he utters a long sentence, or rather a series of sentences (verse 63), that ever seem to be in the making and in which the speaker, one feels, is at any given point uncertain as to what to say next. The sentences are remarkable for the pathetic effort the young man makes to put his best foot forward in a hopeless situation. The verse runs as follows:

\footnotetext{
${ }^{20}$ Or, your right hand.

${ }^{21}$ Some commentators say that Moses provides these details because he wants to prolong his conversation with God, and, when he runs out of the specific uses of the staff, adds an allpurpose statement to further spin out the answer.

${ }^{2}$ The incident is briefly discussed in my article. "The Qurªn as Literature, "Religion and Literature, XX, I (1988), 57.
} 
You see, when we took refuge by the rock-l forgot the fish-it is Satan, and Satan alone, who caused me to forget to mention it-it coursed its way into the sea. Strange!

As one can see from this rather tortuous statement, the young man is more anxious to vindicate his own position than to explain what happened. And when he does come round to speaking about the diving fish, he makes short work of it. But he takes time out to blame Satan. and anticipating Moses' comment, offering a one-word evaluation of the whole event: "Strange?"23 His inability to provide a simple and coherent answer is evidently humorous-and is meant to be so.

\section{The Patience of Moses}

"Ye have heard of the patience of job," we read in James 5:11.24 The Qur'ān (18:65-82) tells of the patience of Moses, ${ }^{25}$ who meets Khidr, expressing his wish to bear him company. Khidr warns him that he (Moses) lacks the necessary patience--meaning, as we soon find out, that Moses would find it hard to put up with the seemingly strange acts that Khidr as God's agent might perform. Moses promises to be patient, but of course proves wrong at the first step (when Khidr makes a hole in a boat), and at the second (when Khidr kills a young boy), and at the third (when Khidr repairs a wall without demanding remuneration from the owner). The situation has a light but constant streak of humor. We shall have more to say more about it a little later.

\section{A Close Brush}

S. 7:43 describes Moses' "encounter" with God. Moses expresses his wish to see God. Instead of rejecting the request, God tells Moses that He would manifest Himself to the mountain, and that, if the mountain is able to bear the impact of the divine epiphany, Moses should be able to see God. The mountain is crushed under the impact, and Moses, too, falls down, having fainted. As we shall explain later, the incident is humorous in a Bergsonian sense.

\footnotetext{
${ }^{23}$ The word a a aban is usually interpreted as the second object of Ittakhadha, but grammatically $1 t$ is possible to take it as an independent unit (see Abü 'I-Qãsım Mahmüd ibn 'Umar azZamakhsharī, Al-Kashshăf 'an Haqă’’q al-Tanzīl wa 'Uyūn al-Aqāwīl 4 vols. (Beırut: Dăr alMa'rifah, n.d.). 11, 396, and that would seem to make more sense in view of the psychological state the young man is in: he is not very sure of how he should express himself, and so is likely to utter a confused and broken rather than a smooth and eloquent statement.

${ }^{24} \mathrm{King}$ James Version.

"Of course the use of the word "patience" for Job has a different signification (The Revised Standard Version substitutes "steadfastness" for it) than its use has for Moses.
} 


\section{A Man of Profound Judgment}

S. $74: 18-25^{26}$ portrays a typical Meccan leader who is apprehensive of losing his followers to the religion of Muhammad. Sitting in the company of some of his followers, who are waiting to hear his considered view of the new religion, he goes through a routine which is obviously funny: first he manages to go into deep thought; then he raises his head, knitting his brows; then he steps back, declaring in a solemn tone that the effect of Muhammad's revelation on its listeners is comparable to the effect magic usually has on an audience--the implication being that the revelation, though eloquent, is of human and not divine provenance. The Qu'rān, it is obvious, is drawing a caricature.

\section{The Better Part of Valor}

The Medinan suras discuss the Hypocrites (munafiqūn) at some length. The weakness of the Hypocrites' faith of ten became manifest when a sura enjoining fighting was revealed. On at least three occasions in the Qu'ran, the reluctance of the Hypocrites to fight for Islam is described in terms that can be called humorous. In 627 when the Meccan Confederate forces attacked Medina, the Hypocrites, instead of supporting the Muslims in defending the city, acted in a questionable manner. S. 33:20 speaks of the cowardice in the face of the Meccan invasion-of their ostrich-like behavior even after the Meccans had withdrawn:

They suspect that the Allies have not yet left. And should the allies come back, these people would very much like to be out in the countryside with the Bedouin, sounding about your situation from there. And had they been with you, they would hardly have fought. if at all.

This verse, which depicts so well the mentality and attitude of the Medinan Hypocrites, could be cited to illustrate the relationship between discretion and valor as conceived by Falstaff. In a similar vein is $S .47: 20$, "When a sura with unambiguous content is revealed, containing mention of fighting, notice those with sick hearts looking at you with the eyes of one in a mortal daze." Finally, there is S. 9:127: "Each time a sura is revealed, they look at one another, (as if asking) 'Is anyone watching you?' "

\section{Other Instances}

(1) S. 19:3-8 reports Zechariah's prayer for a son and his reaction upon being told that his prayer shall be granted. Having mentioned that all the odds are against the birth of a child--he is too old and his wife is sterile-Zechariah says (at the end of verse 5) that in praying for a son he is asking for a special favor from God (min ladunka). The prayer shows his great faith in God. But no

\footnotetext{
${ }^{26}$ Briefly treated in Mir, The Qur'an as Literature, "Religion and Literature" 62-63.
} 
sooner is he told that he will be blessed with a son than he starts to wonder as to how it will come to pass: "He said, "My Lord, how can I have a son when my wife is barren and I myself have reached a decrepit old age?'"

(2) S. 6:75-83, if interpreted as representing Abraham's characteristic way of confuting his opponents, ${ }^{27}$ would appear to be quite humorous. With his tongue in his cheek, Abraham, the young rebel, on several occasions, relieves the anxiety of his people by announcing his acceptance of their deities-first of a star, then of the moon. then of the sun-only to plunge them each time into deeper anxiety by rejecting the deities in the end. He literally "plays" with his people-raising their hopes and then dashing those hopes, and repeating the process all over-the people becoming victims of an elaborate "set-up."

(3) In S. 37:91-92 Abraham's mockery of the idols in the temple is not without humor. He probably points to the food of ferings placed before them as he says: "What's the matter with you that you don't eat? What's the matter with you that you don't speak?"

It is possible that the Qur’an contains other instances of humor. ${ }^{28}$ Elton Trueblood, in his search for humor in the Gospels, noted that "sometimes this did not appear until the text had been read and reread many times." ${ }^{\text {29 }}$ The same may be said about the Qur'an. Indeed, centuries of exegetical tradition has so encrusted the Qur'anic text and so conditioned the minds that the very idea of humor in the Qur'an would sound to many a contradiction in terms. I have tried to show that this is not the case. The next step is to consider the technique and function of Qur'anic humor.

\section{TECHNIQUE AND FUNCTION}

\section{Technique}

Since the Qur'an contains only a few instances of humor-it is only in the vestibule of faith, as Niebuhr would say, that we find humor one cannot perhaps speak of the existence of an elaborate Qur'anic technique to achieve humor. Nevertheless, the instances noted in the preceding pages suggest, upon analysis, certain points that are worth noting.

To begin with, Qur'anic humor is mainly, either humor of situation or humor of character..$^{30}$ Humor, in other words, arises out of a situation that is perceived as having a comical dimension, or from the way in which an individual conducts himself.

\footnotetext{
${ }^{27}$ Rather than as representing Abraham's own intellectual-spiritual journey.

${ }^{2}$ Like S. 27:44, where the Queen of Sheba, asked by Solomon to enter the crystal palace. thought that she was stepping into deep water, and so bared her legs (i.e. tucked up her trousers).

${ }^{\approx}$ Trueblood, The Humor of Christ, p. 9.

${ }^{30}$ In the final section we shall note a few examples of another type of humor--verbal humor--in the Qur'an.
} 
The principal device used by the Qur'an is that of irony. ${ }^{31}$ Irony is "the perception of a clash between appearance and reality, between seems and is, or between ought and is." ${ }^{\text {32 }}$ In S. 18:65-72 (Moses and Khidr), humor is caused by an ironic contrast between commitment and conduct. Khidr says that Moses, if he came along with Khidr, would not be able to put up with Khidr's seemingly strange acts. Moses assures him that he will remain calm and composed. But we as readers have a sneaking suspicion that Moses will have difficulty living up to his resolve. "Nothing," says Pascal, "produces laughter more than a surprising disproportion between that which one expects and that which one sees. ${ }^{n 3}$ The disproportion is quite glaring in the present case. Moses fails to keep his composure. The fact that he fails to do so on three consecutive occasions, in addition to the fact that, after the first occasion, we suspect that he will fail again, imparts to the whole situation what Bergson calls the quality of automatism. Speaking of the repetition of a physical movement as a source of humor, Bergson writes:

If I notice it [physical movement] and it succeeds in diverting my attention, if $I$ wait for it to occur and it occurs when I expect it, then involuntarily I laugh. Why? Because I now have before me a machine that works automatically. This is no longer life, it is automatism established in life and imitating it. It belongs to the comic. $^{34}$

It is not difficult to see that, had Khidr not decided to part company with Moses, the result would have been, "by a series of cumulative effects, a hilarity capable of unlimited expansion." "35

In S. 20:17-21 (Moses and his staff) we see a clash between what we might call the real intent of the question Moses has been asked and Moses' understanding of that question. The question-"What is in your hand, Moses?"obviously is not meant to prompt Moses to detail the uses of the staff, but to prepare him to recelve the miracle of the staff, for the question, we must remember, is asked immediately after Moses is made a prophet ("And I have chosen you [to be a prophet], so listen carefully what is being revealed to you" 20:13). The fact that Moses disregards this context, does not even suspect that

\footnotetext{
31 For a detailed study of irony in the 12th sura of the Qur'an, see Mir, "Irony in the Qur'an: A Study of Sura 12 " for thcoming in the Journal of the American Academy of Religion.

*Northrop Frye, Sheridan Baker, and George Perkins, The Harper Handbook to Literature (New York: Harper \& Row, 1985), p. 250. 53.

${ }^{s}$ Quoted in Max Eastman, The Sense of Humor (New York: Octagon Books, 1972). pp. 152-

"4 Comedy: An Essay on Comedy, by George Meredith; Laughter, by Henrı Bergson, Introduction and Appendix; The Meaning of Comedy, by Wylie Sypher (Baltimore and London: The Johns Hopkins University Press, 1980: pb. rpt. 1956, Doubleday Anchor edition), p. 81.

Ibid., p. 69.
} 
the question might be significant in some way, has ironic humor. At any rate, he could have replied with a simple "This is my staff," but he goes off the tangent, as it were--and keeps going, the very length of his answer being comical.

The episode is ironic in another way as well. Moses' description of the staff, one cannot help feeling, is offered in affectionate terms: It is, after all, a staff that has been his companion for a long time and has given him good service. But, when instructed to cast it on the ground. Moses watches the staff turn into a live serpent, and steps back in horror. The same staff which he knew so intimately he no longer recognizes and has to be reassured. A similar kind of irony is found in $S$. 19:3-8, where Zechariah, having been told that his request for of fspring has been accepted, asks for a "sign." It is true, as commentators point out, that Zechariah wants reassurance, for in verse 10 he requests a sign. But the very fact that Zechariah, who a few moments before expressed his deep faith in the ability of God to bless him with a son in an apparently impossible situation, is now citing the same situation to demand reassurance is not without humor.

S. 7:143 furnishes an instance of ironic contrast between the ideal and the real. One of the examples Bergson gives to illustrate his theory of laughter ${ }^{36}$ is that of the runner who falls: the sudden stoppage of movement, "the momentary transformation of a person into a thing, ${ }^{\text {"37 }}$ gives rise to amusement and laughter. Something similar happens in S. 7:143. Moses, full of vitality and intensely desirous of seeing God with his eyes, collapses the moment God manifests Himself to the mountain. Movement is replaced with stillness, life with inertness. Interestingly, Bergson uses the example in a metaphorical sense also--"runners after the ideal who stumble over realities" ${ }^{38}$-and this, too, applies to Moses in 7:143, where not only does he fall physically, he aspires af ter the unattainable ideal of seeing God with his eyes, and stumbles over the reality of his finite capacity.

The story of Moses and the young man has an ironic ending. Having made a valiant attempt to explain the disappearance of the fish into the sea, the young man, we can imagine, stands there, awaiting a possible rebuke from Moses. He does not know that the disappearance of the fish was a divinely appointed sign: precisely at the place where the fish disappeared Moses was supposed to meet Khidr, an agent of God, and Moses, upon hearing the story, becomes excited, forgets about his fatigue and the food, and of course completely disregards the youth's explanation, and rushes back to the spot where the fish had disappeared into the sea. The young man must have wondered why he bothered to provide such a long explanation.

\footnotetext{
*"Something mechanical encrusted on the living." ibid.. pp. 84, $92,97$.

"Ibid., 97.

Ibid., p. 69 .
} 
S. 37:91-92 (Abraham and the idols) is ironic in a satirical way. The same deities on behalf of which their devotees would make such a fuss are powerless to act:they cannot reply to a question that is asked of them, and they have-the pity of it!-no appreciation of the offerings their devotees have so lovingly placed before them.

Besides irony, four other devices are used in the instances given above, and we will note them briefly.

In S. 20:17-21 we see the use of anticlimax. In the first part of the dialogue between God and Moses, God is the speaker, and He speaks of subjects sublime and serious-deity and prophecy, sacred ground and prayer. All of a sudden God asks Moses what he is holding in his hand, and Moses launches forth into the uses of his staff. The drop from the sublime to the mediocre, from the highly spiritual to the utterly mundane, is only too obvious, and creates a humorous effect.

In S. 18:60-64, effective use is made of circumlocution. The young man's consternation at being asked by Moses to present the food leads to a desperate attempt on his part to absolve himself of any responsibility for the disappearance of the fish, the result being a tortuous statement reflecting the confused state of mind of the speaker.

In S. 74:18-25 caricature is used to expose pretense: the details of the "thinking process" through which the Quraysh leader arrives at his judgment make him look ridiculous.

Finally, one of the verses cited above makes use of rhythm to create humor. This needs to be explained in some detail. Stephen Leacock calls the translating of humor from one language into another "an almost impossible feat." ${ }^{39}$ The feat, one might say, becomes truly impossible in a case where rhythm is also involved. Consider S. 7:143, part of which reads, in translation: "And Moses fell down unconscious." This statement, taken by itself, has no humor in it. But upon reading the whole verse carefully one notices that the Arabic-wa kharra mūsa sa'iqa $\bar{a}-$ is, in respect of rhythm, quite distinct from the rest of the verse. Further reflection shows that, with a slight variation, the said part is composed mostly of disyllabic words and is neatly iambic. The result is a tripping beat that makes wa kharra müsa sa'iqa stand out in the verse. This prominence imparts to it a certain humorous effect. "In the highest class of comic verse," writes Stephen Leacock, "the very ease of the rhythm becomes, as it were, a source of humor." ${ }^{n 10}$ The Quranic verse in question is not an instance of comic poetry. But one of the ways in which we pass a humorous comment on a faux pas or comical conduct is by humming a light tune or uttering a rhyming or rhythmic remark, and it seems to me that wa kharra mussa $s a^{e} i q \bar{a}$, with its "ease of rhythm," constitutes such a comment.

Stephen Leacock. Humor and Humantty (New York: Henry Holt and Company, 1938), p. 127. See also p. 120.

*Ibid. p.26. 
A word about the placement of humorous content in the Qur'ann. Such content is of ten put in the middle of a verse or passage. This serves a two-fold purpose ( 1 ) to use the beginning and the end of the verse or passage as buffers to maintain the otherwise solemn tone of scripture, (2) to keep the reader's mind focused on the appropriate lessons to be drawn. As an example, we shall look at S. 20:16-21. The passage is preceded by a set of verses in which Moses is commanded by God to worship Him, to be mindful of the hereafter, and to reject those who would draw him away from the path of God. It is followed by a command to go to Pharaoh and ask him to give up his evil ways. The same technique is used in the Biblical passage (Luke 18:2-5) which serves as the epigraph of this article. The passage is preceded by the following verse: "And he told them a parable, to the effect that they ought always to pray and not lose heart." It is followed by this statement: "And the Lord says, "Hear what the unrighteous judge says. And will not God vindicate his elect, who cry to him day and night. ..?"

\section{Function}

Elton Trueblood claims that, in interpreting the Bible, there are cases in which "the recognition of humor is a genuine solvent. ${ }^{\text {mI }}$ In Chapter 5 of his book he discusses several problematic passages in the Gospels and argues plausibly that the recognition of a humorous intent in those passages makes for a much more satisfactory explanation of them than has so far been offered. Does humor have any hermeneutic value in the Qur’an? There do not seem to be many cases in which failure to notice the element of humor would result in poorer Qur'ann exegesis. But consider S. 6:75-83 (Abraham's hujja ["argument"] against his people). Of the two principal interpretations of this passage, the element of humor, if its presence in it is conceded, would give one interpretation (namely, that Abraham was using humor to expose the absurdity of his people's belief in the deity of the heavenly objects) precedence over the other (namely, that the passage recounts Abraham's own spiritual development). S. 37:91-92 suggests that Abraham the prophet did not mind "playing" with his opponents. If so, then 6:75-83, too, should be interpreted in a manner that is in keeping with Abraham's character.

"Humor," says Hyers, "does tend to negate the distance between the sacred and the profane, and to annul the distinction between the holy and the unholy." 42 I am not sure this would be completely true of Qur'anic humor. Still it is interesting to note that the two situations in the Qur'an in which the holy and the prof ane ${ }^{43}$ come closest to each other-S. 7:143 (Moses requesting God to manifest Himself to him) and S.20:17-21 (Moses explaining, upon being

\footnotetext{
${ }^{41}$ Trueblood. The Humor of Chrish p. 10. See also Jonsson, Humor. Pref ace lopening paragraph.

"Hyers. "The Comic Prof anation of the Sacred." Holy Laughter. p. 21.

${ }^{43} 1$ use the word "profane" in a neutral sense here implying a simple absence of the holy or the sacred.
} 
asked by God, the uses of his staff)-involve use of humor. The humor is, moreover, not incidental to the two passages but is found, to use Niebuhr's phrase, as "a suffused element" in the scenes depicted. Still further, it is meant to accentuate some of the Qur'anic theological teachings. S. 7:143 does not so much prove the utter transcendence of God as it establishes the point of contact between God and man: God is so far and yet so near-and, conversely, so near and yet so far. The humor of the passage is two-pronged: there certainly is a barrier between God and man, and the attempt to cross that barrier can produce laughable results; on the other hand, the divine response to the attempt is not all wrath and fury, but has an element of play or humor in it-if Moses wishes to see God, then God will, instead of rejecting his request outright, "play along." Likewise. S. 20:17-21 brings into relief a certain aspect of the psychology of prophets. A prophet never craves or desires the of $f$ ice of prophethood; he is chosen by God to serve as a prophet. Nor does a prophet, after being made a prophet, go hunting for revelation. He is, in other words, to be distinguished from a soothsayer, who is eager to obtain information about the ghayb (S. 81:24)-the non-phenomenal part of Reality. As we learn from another Qur'anic passage (S. 26:12-14), Moses, instructed by God to present himself as a prophet before Pharaoh, feels uneasy and suggests that Aaron, his brother, be sent instead. ${ }^{41}$ S. 20:17-21 makes the same point, using humor: a man whom God would choose to be prophet is so far from harboring any ambitions of becoming a prophet that his immediate and involuntary reaction upon being appointed one is that of surprise and bewilderment. On receiving the miracle of the staff, Moses is so baffled that, instead of staying put and analyzing the situation, he takes to his heels. Likewise, when he is asked by God as to what he is holding in his hand. Moses might have sensed that the question had something to do with his appointment as prophet, for, as noted above, it was only moments ago that he was made a prophet. But he takes the question in its simple, literal sense and responds accordingly.

Humor is used by the Qur’an for purposes of characterization. The first three instances of humor cited in Section II involve Moses, and each one of them highlights a certain trait in Moses' character. The passage about Moses and his staff reveals two absolutely lovable traits of his personality: his simplicity and natural warmth; the passage about Moses and Khidr shows Moses to be somewhat impulsive; and the passage about Moses and the young man suggests Moses to be a person who inspires awe and reverence in his followers--it is because of the reverential awe in which the young man holds Moses that he, the young man, stumbles all over himself in explaining the fate of the fish.

While Moses is involved in several instances of humor found in the Qur'ān, he himself does not use humor; in fact, considering his character, it is difficult to visualize that he would make use of humor. Abraham, however, makes use

"See Amos 7:14-15. in which Amos, responding to the suggestion of Amaziah, the priest of Bethel, that Amos stop prophesying at Bethel, pointedly remarks that he did not become a prophet of his own volition but was commanded by God to prophesy. 
of humor to drive home certain truths to his people. One might even say that, in his attempt to put the idolators to shame. Abraham is quite ready to play practical jokes-as is obvious from his criticism of the idolators (S. 37:91-92) and his "conversation" with the idols (S. 6:75-83; see also S. 21:62-63).

\section{HUMOR AND QUR'ANN TRANSLATION}

I would like to close with a few remarks on translating the Qur'ān. If one holds that scripture cannot have any humor in it, one will be at a loss to recognize it should it be present in a passage, and as a result will fail to convey it in translating it. ${ }^{45} \mathrm{~A}$ few examples will make this clear. (For purposes of discussion, A.J. Arberry's Qur’ann translation will be used.)

The first part of (S. 63:5 reads: wa idha qĩla lahum ta'alaw yastaghfir lakum rasulu 'llahi lawwaw ru'usahum. The Arabic phrase lawwaw ru’ūsahum contains scornful humor; the Hypocrites intend, by "shaking their heads," to make fun of the invitation extended to them. But this is not brought out by the following translation of A.J. Arberry (translation of the Arabic phrase italicized $)^{46 *}$ And when it is said to them, "Come now, and God's Messenger will ask forgiveness for you,' they twist their heads." Lawwa in this context means not "twist"--that would be too literal and not at all in keeping with the spirit of the sentence--but something like "wag" or "jiggle." In fact one thinks of Lamentations 2:15, which, too, describes a situation involving mockery: "All who pass along the way clap their hands at you; they hiss and wag their heads at the daughters of Jerusalem." 47 Clearly, "wag" or "jiggle" can be playful or amusing in a way that "twist" cannot be.

S. 24:63 contains the phrase alladhina yatasallalūna minkum liwadhan. The Arabic phrase has a definite humorous touch to it: it depicts a group of men who, when they suspect that they will be called upon to undertake some important, possibly dangerous, mission, do the vanishing trick, taking cover behind one another. But the element of humor is scarcely present in the following translation by Arberry: "those of you who slip away surreptitiously." Amīn Ahsan Islāhī's Urdu translation, which employs the half-humorous verb khisakna (approximately: "to sneak away, give the slip"), is much closer to the

\footnotetext{
45 In fact a vicious circle seems to exist here: the fallure to see humor in a text may affect one's translation of 1 t, and the received translation of a text may render one unable to see humor in it. See Trueblood The Humor of Christ. p.18, who, af ter noting the inadequacy of the Authorized Version from the point of view of conveying the element of humor in the Bible. says that "In this situation the newer translations are of ten helpful" (see, in this connection, his comments (pp. 87-88) on the New English Bible's translation of Luke 22:24-27). Of course no such distinction can be made between the existing translations of the Qur'ān.

* The Koran Interpreted (London: Oxford University Press, 1984).

${ }^{47}$ See also Psaim 22:7, "All who see me mock at me, they make mouths at me, they wag their heads."
} 
spirit of the Arabic: jo ek dūsre $k \bar{I}$ ar lete hu'e khisak jaya karte rahe hain ${ }^{48}$ ("those who are wont to sneak away, taking cover behind one another"). We are all too familiar with the stock scene in comic movies where a group of cowards try to avold a danger by taking cover behind one another.

Likewise, in S. 33:20, neither the delicately humorous connotations present

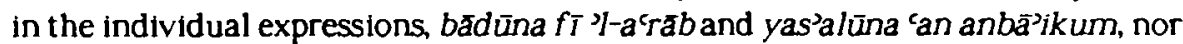
the comical nature of the overall picture drawn in the verse is present in the Arberry translation: "They think the Confederates have not departed; and if the Confederates come, they will wish that they were desert-dwellers among the Bedouins asking for news of you. If they were among you, they would fight but little" (cf. the translation given in Section II, above).

Finally, consider Arberry's translation of S. 18:63:

He said. 'What thinkest thou? When we took refuge in the rock, then I forgot the fish-and it was Satan himself that made me forget it so that I should not remember it-and so it took its way into the sea in a manner marvellous.'

This rendering, apart from the fact that it is incorrect in part, ${ }^{49}$ falls to give any idea of the perplexed state of mind of the speaker, in turn failing to give one an understanding either of the character in question or of the situation in general (see the translation provided in Section II, above).

One final point. The present study consists of no more than notes on the subject of humor in the Qur’an. Trueblood, we noted, saw the need to read and reread the scriptures in order to dig out the now hidden humor in those texts. I have tried to show that the Qur'an does possess an element of humor. The field is wide open for further study.$^{50}$ or, one might say, for further digging-for the nature of the exercise is "archeological" in a rather literal sense. ${ }^{51}$

Department of Near Eastern Studies

MUSTANSIR MiR University of Michigan

Ann Arbor, Michigan

${ }^{48}$ Lahore (8 vols.), 1967-1980, IV, 563, 567.

- Arasayta in this context does not mean "What thinkest thou? but something like "Well. you seer See my Verbal Idioms of the Quradn (Center for Near Eastern and North African Studies, University of Michigan, Ann Arbor, 1989), pp. 11 and 135.

${ }^{50}$ An interesting topic would be a comparative study of humor in the Qur'an and Hadith. Another topic is the use of hurnorous wordplay in the Qurasn.

${ }^{51}$ An earlier version of this article was presented at the Center for Middle Eastern Studies, University of Chicago, October 1990. 